\title{
The Role of Diplomacy in the international control of arms trade
}

\author{
Abdelrahman Gajum \\ phd Candidate \\ DOI: 10.29322/IJSRP.10.08.2020.p104119 \\ http://dx.doi.org/10.29322/IJSRP.10.08.2020.p104119
}

\begin{abstract}
The arms trade has become a key one of the most widely used instruments in arms suppliers. It has led to "outdatedness" of traditional security and diplomacy instruments, such as formal alliances, the deployment of military forces abroad and threats of military intervention.

Today's leading world economic and military powers will be less likely to decide to intervene directly with their armed forces in a particular country that is considered hostile, compared to the model that involves arming a friendly country by providing weapons. A factor that contributes to the increase in the application of this model is the reduction of other classical instruments of diplomacy, like development aid.

Many countries in the world have publicly recognized the existence of cooperation between state institutions and civil society in the negotiation process as crucial for the adoption of the Arms Trade Treaty in 2013.
\end{abstract}

Index Terms- Arms.World.Trade.Economic.Diplomacy.

\section{INTRODUCTION}

$\mathrm{T}$ he aim of arms trade control is to limit the number of weapons in use and to regulate their use on the basis of bilateral or multilateral agreements or arrangements. On the other hand, the disarmament process aims to eliminate a number of categories of weapons systems. The proliferation of weapons of mass destruction in the world poses a serious threat to global security.

Armed conflicts in modern world are characterized by unconventionality and distance in relation to wars defined by theory, ie "classic" armed conflicts, which were dominant during the twentieth century. Based on the analysis of contemporary conflicts, it can be concluded that they are determined by a form that is focused on predominantly unarmed activities, ie that the armed forces are used in a selective manner, and that their predominant role is to deter a potential aggressor.

In the conditions of globalization, ie growing interdependence of the market, there are numerous factors that influence the nature of the development of relations associated with the dominance of economic, media, cyber and energy elite,

1 Mitrović M., "JAVNA DIPLOMATIJA U PARADIGMI HIBRIDNOG KONCEPTA SUKOBA", Ministarstvo odbrane Republike Srbije, Institut za strategijska istraživanja, VOJNO DELO, 2/2018, (2018), str. 309. which is increasingly out of ownership and control by the state or nation.

Consequently, there is a separation of interests and goals of separate centers of power, which are not always harmonized and compatible with national interests. Under the given conditions, "hybrid endangerment of national security has various manifestations, which are conditionally called hybrid warfare, but they do not represent war in the classical sense. Namely, hybrid forms of security breaches mean unarmed forms of action that disrupt the state's defense and other strategic capabilities in resistance to aggression."1

"At the state level, there are three key categories that are link between the economy, national security and foreign policy. First, economic well-being is one of the primary state interests. Secondly, economic potential is directly related to power, and therefore, to national security. Finally, economic needs are one of the strongest internal sources of foreign policy, and, on the other hand, economic power is used to achieve important foreign policy goals." 2

Economic security can be viewed from two aspects, namely:

- from an individual aspect

- from the aspect of the state.

At the international level, economic security has gained its legal basis and protection. Based on the adoption of the Covenant on Economic, Social and Cultural Rights, which, in fact, represents the concretization of the previous Universal Declaration of Human Rights adopted by the United Nations. Unlike the aforementioned Declaration, the Covenant on Economic, Social and Cultural Rights has created an obligation for states to adopt its provisions. The Covenant on Economic and Social Rights lists a number of rights, such as the right to social security, the right of every person to be able to work and earn, trade union organization, etc.

In relation to economic security, the elementary values that are protected and controlled are economic and material goods. Namely, the mentioned values are protected because poor or devastated economic conditions can have a negative effect on the internal political stability in a certain country with possible farreaching consequences in terms of national security. The problem of economic security from the individual level is complicated and

2 Terriff, Terry, etc., „Security Studies Today“, Blackwell Publishers Inc., Malden, (1999). pp. 136, 137. 
increased to the level of becoming a serious security problem for individual and national security.

The level of poverty in the countries of the so-called Third World has further raised with the departure of migrants and their families, primarily in search of work in more industrialized countries. This, on the other hand, brings about the emergence of nationalist and xenophobic activities by the domicile population towards newcomers, especially in Western European countries, due to the working middle class, which is afraid for its own existence, ie has fear of possible job loss.

Conditions of constant political dissatisfaction and instability in the poorest parts of the world can pose a threat to the economic security of even the richest countries and communities in the world. The leading manufacturing and marketing sectors of the United States, the European Union, and Japan are fundamentally determined by the existence of trade links with a large number of developing countries.

Economic power can be transformed into security power, including military power. Namely, it is known that weapons are paid for with money.

The economic system of a certain state produces material goods and provides the financial means necessary for the army, whose task is to protect national security.

The material goods on which the economic power of a certain state is based are:

- Natural Resources;

- material goods;

- intellectual or protected goods, capital and

- Human Resources.

Economic power can be defined as "a functional substrate of military power, both for offensive and defensive intentions. Economic instruments are important means of the state formed to realize its national interests. Especially in the age of interdependence with these means, economically strong states have the opportunity to influence in order to change the attitudes and behavior of other states. In practice, states most often use economic instruments to reward or punish a state, to induce it, or to force it to behave in a certain way. Countries with strong economies, in addition to the ability to strengthen the armed forces, also have a wider range of instruments for exercising influence. The growing interdependence of the international economic system provides more opportunities for the application of economic instruments that affect others, and a strong economy provides greater capacity for the successful application of these instruments."

Economic compulsion is a way of using state power, such as the use of force, to ensure the achievement of political goals. There is a high degree of correlation between the power of the national economy and the influence on other countries. in other words, the greater the ability to exert influence on other states, the greater the ability to defend against the imposition of influence by other states.

3 Terriff, Terry, etc., „Security Studies Today“, Blackwell Publishers Inc., Malden, (1999). pp. 136-148.

${ }^{4}$ Modelski, G., "A Theory of Foreign Policy", Pall Mall Press, London, (1962), pp. 4-11.

5 Prvulović V., "Ekonomska diplomatija", Grmeč, Beograd, (2001)., str. 150.

This publication is licensed under Creative Commons Attribution CC BY.

http://dx.doi.org/10.29322/IJSRP.10.08.2020.p104119
Policy makers play a crucial role as representative agents or mediators. Although they are not neutral mediators, because their primary duties belong to the community, they constitute the essence of an instrument whose function is mediation between that community and the outside world. ${ }^{4}$

There are a large number of means within foreign policy procedures that are related to the economy and that can be classified into those procedures that are applied when relations between countries are normal, and coercive economic means. Within coercive means, the most commonly used are those that can generally be called economic sanctions or embargoes.

Professor Prvulović states that lately, economic sanctions have often been applied, as a foreign policy tool for resolving certain international issues, for various reasons (either unilaterally by individual states or regional organizations, or multilaterally by Security Council decisions). ${ }^{5}$

The nature of economic sanctions can range from the cessation or suspension of bilateral relations imposed by one state to another, or the complete cessation of cooperation only in a specific part or suspensions by certain organizations, such as blockade or isolation of the country, sanctions on arms imports, and strategic products., all the way to complete isolation, ie interruption of all economic communications and traffic, including cultural and sports areas, (examples are the sanctions of the international community, ie the Security Council and the EU against the Federal Republic of Yugoslavia in 1992).

The reasons for imposing sanctions are quite different from previous examples from practice, from punishing racist laws and apartheid (South Africa), the inadmissibility of internal regulation, or an alliance with another competing force, which is declared a threat to national interests (Cuba), aggression on neighboring country (Iraq), non-acceptance of the elected president (Haiti), human rights issues (FRY). That's just part of the list. "6

"The most common political reasons are the overthrow of a government, economically when a country should be punished for its market penetration or for protecting its own production, and among the military-strategic ones to preserve the monopoly of arms production, weaken other people's military capacities and prevent sales to third countries." 7

"Another type of coercive action is armed rebellion. "A rebellion is a mass action individually and according to the number of an indefinite group of people for the purpose of violently overthrowing a social or state system or for opposing a body or a measure of state power. It is a sharp form of political struggle and it occurs due to the aggravated social relations and harsh actions of the state government, and the reason for it is often some extremely unpopular measure of power. Rebellion is often called the conflict of a nationally oppressed ethnic group with the state or national community in which it lives, or even a form of resistance to imperialist and colonial politics. A rebellion is armed if its participants, all or part of it, are supplied with weapons or

6 Prvulović V., "Ekonomska diplomatija", Grmeč, Beograd, (2001)., str. 151.

${ }^{7}$ Stajić Lj., "Osnovi bezbednosti”, Policijska akademija, Beograd, (2003), str. 190. 
weapons suitable for attack and defense. If the rebellion is led by the army, then it is a military rebellion. "8

"Civil war is an armed struggle between class, national, political or other antagonistic groups within a state, to achieve certain political and economic goals."

Weapons or military force at the local level when it comes to the relations of certain individuals or groups towards others. cannot be completely excluded, so, in accordance with that, it is necessary to elaborate what it means to interfere in the internal affairs of a certain state, what violence is and the like. It is necessary to strive for every person on the planet to have a place to live, to harmonize relations between people, to make available to every person what is essential for a normal life: water, food, a healthy environment, energy, etc.

"In science one can find views on the relationship between foreign policy, and the defense-military component, in the view that in a period of peace, the military-defense complex contributes to foreign policy, and in a period of war it becomes foreign policy." 10

Viewed through a historical prism, "weapons and military equipment were the exclusive means of soldiers who achieved political goals by force. However, in the modern age, weapons and military equipment are an exceptional instrument of diplomacy, more specifically defense diplomacy. The arms and military equipment trade is a kind of link between defense and diplomacy, which under certain conditions can be used for discreet diplomatic pressures and strengthening political influence abroad. In addition to the undoubted economic benefits from the export of weapons and military equipment, the purpose-built industry also represents a kind of link between diplomacy and the defense system. However, the trade in arms and military equipment poses a number of problems for political structures, as the interests and attitudes of the Ministry of Foreign Affairs and Defense do not always have to be identical with regard to export licenses." 11

The strength of a country's armed force is what affects the degree of reputation it enjoys internationally. The strength of the armed force means the number of people, the quality of weapons, the equipment with appropriate equipment and its readiness to engage in achieving the set tasks and goals. During the so-called Cold War, the United States, within the doctrines of deterrence and containment, introduced huge changes in the previous understanding of the concept of war, that is, it created a concept called "projection of forces on distant battlefields".

The Soviet Union also used military force to conduct foreign policy, resulting in the so-called arms race between the Soviet Union and the United States during the decades of the twentieth century.

At the beginning of the 1990s, the so-called Eastern Bloc led by the Soviet Union was overthrown, that is, it disappeared, so the North Atlantic Alliance or NATO led by the United States of America survived on the historical scene. In that way, an

\footnotetext{
${ }^{8}$ Mijalković, Saša V., "Nacionalna bezbednost", Kriminalističkopolicijska akademija, Beograd, (2009), str. 210-211.

${ }^{9}$ Mijalković, Saša V., "Nacionalna bezbednost", Kriminalističkopolicijska akademija, Beograd, (2009), str. 213

${ }^{10}$ Gavranov, V., Stojković M., "Međunarodni odnosi i spoljna politika Jugoslavije", Savremena administracija, Beograd, (1972)., str. 290-291.
}

This publication is licensed under Creative Commons Attribution CC BY

http://dx.doi.org/10.29322/IJSRP.10.08.2020.p104119 imbalance was established in terms of military forces, which characterized the period of the Cold War, which led to the intensification of military interventions in the practice of modern international relations.

The goal of these military interventions was not related to the occupation and de facto control of a certain territory, but the goal was to impose "own political concepts, ensure vital national interests, support endangered political regimes, secure markets for own industry, protect and control energy and raw material supply routes." maintaining a military presence in important regions and more. Within military interventions, diplomacy has a significant place. It has an obligation to prepare political and legal conditions suitable to justify military intervention, in accordance with the foreign policy of the great powers. "12

In addition to classical diplomacy, various forms of diplomatic methods are used, such as secret diplomacy, diplomacy of pressure by military, political and economic means, and numerous others. War and diplomacy have certain specifics. The activities of diplomacy are primarily realized through protocol flows, with the necessary consideration of the partner side and the third party, with refined and sophisticated forms of communicating certain political views of the leadership of a certain state. War, on the other hand, represents a kind of test of power and means direct opposition of the opponent in order to impose one's own will by using military force.

War, in the essential sense, represents a kind of antithesis to diplomacy. However, both of these forms of manifestation of the political will of the state and its attitude towards foreign countries have the same final goal, ie both forms have the goal of imposing their own political will on the opposite side. The logic of war and the logic of diplomacy are in essence opposed, but they are harmonized to the extent that they both serve the realization of the foreign policy goals of a certain state. War achieves those goals that could not be achieved through diplomacy, and is pursued as long as their purpose exists. When war loses its purpose, then diplomacy is put into function again, which ends the war and establishes a status that satisfies the needs of the foreign policy of a certain state.

The emergence of nuclear weapons had a certain impact on diplomacy, ie the need for communication and avoidance of conflict situations in relations between the blocs that existed during the Cold War. The United Nations was formed, with a similar task as the League of Nations, but, unlike the League of Nations, the Charter of the United Nations, which brought together all countries of the world under its auspices, defined the active engagement of the United Nations in case of violations of its provisions. respect for the influence of great powers on international relations.

The Vienna Convention on Diplomatic Rights and Immunities, which is a kind of documentation of diplomatic law

11 Stefanović-Štambuk J., "Diplomatija u međunarodnim odnosima", FPN i Čigoja, Beograd, (2008)., str. 29.

${ }^{12}$ Freeman W. Chas Jr: Arts of Power - Statecraft and Diplomacy, United States Institute of Peace Press, Washington, D.C., (2002). pp. 79-81. 
on which the regulation of modern diplomacy is based, was adopted under the auspices of the United Nations, in Vienna.

It is safe to say that in modern foreign policy relations, the saying "capital turns the world" dominates. "Namely, it was also confirmed in the security sphere. Despite being regulated by various agreements, the legal trade in conventional arms within the international community still hides secrets that are essentially profitable and the realization of the national interests of the great powers and multinational companies, which are directly involved in this activity. Thus, profit has become a priority in decisionmaking related to the military industry and arms sales. Combined with the interests of political elites and state interests, the arms trade maintains a continuity of overcoming political means that are an integral part of international institutions for maintaining stability, peace, respect for human rights and democracy.

Countries in crisis regions, as end users of the services of developed countries - leaders in the production of weapons, are the most common target group that offers opportunities for political and economic prestige in the security space. Sometimes the authorities of individual countries, in the arms race as a way to increase their own military power, even in the absence of direct armed conflicts, influence the weakening of the living standards of their citizens. In this way, the regions to which some of these countries belong become less popular for investment and economic development. The paper explains the connection between profits and the arms trade, globalization and conflict. The paper relies on official sources on arms trafficking in the world over the past two decades. "13

The dilemmas posed by the international arms trade and faced by decision-making authorities (governments, above all), which relate to arms trade requirements, stem from difficulties in deciding whether a particular arms transfer will be "positive" or "negative". This can best be illustrated by an analysis of the justifications that are usually given for the sale of arms or the grant of arms to a particular state. The arms trade forms a kind of link between defense and diplomacy that can be used to create and develop, often, indirect diplomatic pressures and strengthen influence in the field of foreign policy. In addition to the economic benefits of arms exports, the defense industry is also a link between diplomacy and a country's defense system. However, the arms trade also brings a number of problems to the representatives of the political establishment, given that the interests and attitudes of the foreign and defense ministries of a country do not have to be the same in every situation regarding the issuance of arms export licenses.

\section{AUTHORS}

First Author - Abdelrahman Gajum phd Candidate

13 Petreski D., Rajkovčevski R., "Trgovina oružjem - između globalizacije, sigurnosnih strategija, konflikata i profita", NBP, Nauka, bezbednost, policija,, vol. 17, br. 1, (2012)., str. 89-106. 